\title{
Regulation of zooplankton by suspension-feeding bivalves and fish in estuarine enclosures*
}

\author{
Steen Jesper Horsted ${ }^{* *}$, Torkel Gissel Nielsen ${ }^{* * *}$, Bo Riemann ${ }^{* * *}$, Jan Pock-Steen, \\ Peter Koefoed Bjørnsen***
}

Freshwater Biological Laboratory, Helsingorsgade 51, DK-3400 Hillerød, Denmark

\begin{abstract}
Enclosure experiments were conducted during April, June/July and September in the eutrophic estuary Roskilde Fjord, Denmark, to reveal the effects of inorganic nutrients, suspensionfeeding bivalves Mytilus edulis and planktivorous fish (three-spined sticklebacks Gasterosteus aculeatus) on the zooplankton community $>45 \mu \mathrm{m}$. The addition of inorganic nutrients did not increase zooplankton biomass although it did increase the chlorophyll level, indicating that zooplankton production was not food limited. Filtration by $M$. edulis reduced the number of tintinnid ciliates and rotifers during all 3 experiments, but not the abundance of the larger zooplankton species. Additions of planktivorous fish reduced the densities of larger zooplankton species Acartia tonsa and Pleopis polyphemoides but not of smaller species. An immense increase in numbers of $A$. tonsa and $P$. polyphemoides was observed in enclosures without fish, indicating that the larger crustacean zooplankton is strongly predator controlled. Thus, the qualitative and quantitative development of the zooplankton community in the enclosures was controlled in 2 ways; from the top of the size spectrum by $G$. aculeatus and from the bottom of the size spectrum by $M$. edulis.
\end{abstract}

\section{INTRODUCTION}

Knowledge on the role of predation in regulating the composition of zooplankton communities in pelagic environments has increased markedly during the last 2 decades. Most evidence derives from lakes, and in particular from studies designed to predict effects of nutrient loadings and planktivorous fish on the qualitative and quantitative development of the zooplankton community (e.g. Andersson et al. 1978, Stenson et al. 1978, Henrikson et al. 1980, Goad 1984).

Eutrophication enhances phytoplankton primary production and biomass. Whether this increase is always channelled to higher trophic levels in marine environments is not clear (Nixon \& Pilson 1983). Enclosure experiments have documented enhanced zoo-

- Contribution No. 480 from the Freshwater Biological Laboratory

Present address:

- Danish Institute for Fisheries and Marine Research, Charlottenlund Castle, DK-2920 Charlottenlund, Denmark

-. Marine Biological Laboratory, University of Copenhagen, DK-3000 Helsinger, Denmark

... The International Agency for ${ }^{14} \mathrm{C}$ Determination, Agern Allé 15, DK-2970 Horsholm, Denmark plankton production in response to nutrient loading (Fulton 1984). However, in natural environments successional changes also occur among potential zooplankton predators. In lakes the abundance of cyprinid fishes increases in both absolute and relative terms when going from oligotrophic to mesotrophic conditions (Johansson \& Persson 1986). This change in the fish population will increase predation on the zooplankton community (Henriksson et al. 1980).

The importance of small planktivorous fish in the food web of shallow marine ecosystems is well documented (e. g. Miller 1979, Zander \& Hartwig 1982, Zander et al. 1984). Suspension-feeding bivalves may also play a central role in the energy flow of marine ecosystems (Dame 1980, Kautsky 1981, Cloern 1982), but the impact of suspension-feeding bivalves on natural zooplankton communities is not known.

Most studies of marine zooplankton have focused on meso-zooplankton $(>200 \mu \mathrm{m})$, but since microzooplankters (e.g. tintinnid ciliates and rotifers) are very abundant in estuarine environments and hence account for a large part of the community biomass and clearance (Andersen \& Sørensen 1986, Jonsson 1986), we included species $>45 \mu \mathrm{m}$ in the present study.

The aim of this study was to measure population 
growth of zooplankton $>45 \mu \mathrm{m}$ when different combinations of nutrients, suspension-feeding bivalves and planktivorous fish were added to estuarine enclosures.

\section{MATERIALS AND METHODS}

Experiments were conducted in the eutrophic estuary Roskilde Fjord, Denmark, during spring (5 to 28 April), summer (17 June to 3 July) and autumn ( 8 to $25 \mathrm{Sep}$ tember) 1986 , at temperatures ranging from 0 to $22^{\circ} \mathrm{C}$. Sixteen transparent plastic enclosures (diameter $1.5 \mathrm{~m}$. depth about $3.5 \mathrm{~m}$ ) were filled with water from the fjord at the beginning of each experiment and fixed to a pontoon bridge (for further details see Riemann et al. 1988: companion paper). The enclosures were manipulated in duplicates by the addition of nutrients, suspension-feeding bivalves and planktivorous fish (Table 1).

Eight enclosures were fertilized by the addition of $0.67 \mathrm{~g} \mathrm{NO}_{3}-\mathrm{N}$ and $0.10 \mathrm{~g} \mathrm{PO}_{4}$-P per enclosure each time the enclosures were sampled. Mytilus edulis corresponding to 279 to $345 \mathrm{~g}$ wet weight made up by 333 to 569 individuals of 15 to $22 \mathrm{~mm}$ shell length were added to half of the enclosures. The filtration by the mussels added to each enclosure corresponded to filtration of the natural population in Roskilde Fjord (Riemann et al. 1988). The mussels were distributed in 3 Japanese pearl nets and suspended at depths of 1,2 and $3 \mathrm{~m}$. The role of planktivorous fish was studied by adding $10 \mathrm{~g}$ wet wt of three-spined sticklebacks Gasterosteus aculeatus (corresponding to 20 to 351 -yr-old fish) to 8 enclosures. The biomass corresponded to the natural abundance of planktivorous species in Roskilde Fjord

Table 1. Enclosure manipulation. C: control; $M, F, N$ : mussels, fish and nutrients, respectively. All treatments were duplicated

\begin{tabular}{|llllll|} 
& \multicolumn{2}{c}{- Nutrients } & & \multicolumn{2}{c|}{ + Nutrients } \\
& - Fish & + Fish & & - Fish & + Fish \\
\hline - Mussels & $\mathrm{C}$ & $\mathrm{F}$ & $\mathrm{N}$ & NF \\
+ Mussels & $\mathrm{M}$ & $\mathrm{MF}$ & $\mathrm{MN}$ & MNF \\
\hline
\end{tabular}

(Gislason 1980). At the end of each experiment water from the enclosures was filtered through a large 3.5 mm mesh net, to collect the added fish

Mussels and fish were collected in Roskilde Fjord and the adjacent Isefjord and acclimated to ambient conditions in a well-box for 4 to $5 \mathrm{~d}$ prior to the experiments.

Sampling program. Salinity was measured at the beginning of each experiment, while temperature was measured on each sampling day. Zooplankton was sampled once at the beginning and once at the end of the April experiment, whereas triplicate samples were taken. every second to fourth day during the June/July and September experiments. Water was sampled from 5 depths in the enclosures, using a $5 \mathrm{l}$ plexiglass water sampler. Water samples from the different depths were mixed, and 25 and $10 \mathrm{l}$ samples were filtered through 140 $\mu \mathrm{m}$ and $45 \mu \mathrm{m}$ mesh nets, respectively. Samples were fixed in buffered formalin ( $2 \%$ final concentration). Zooplankton was counted, identified and measured using a settling chamber and an inverted microscope.

Abundance data and length measurements (to the nearest $1 \mu \mathrm{m}$ ) were converted to biomass and clearance (assuming that zooplankton $>45 \mu \mathrm{m}$ ingest particles within the same size range) according to data from the literature (Table 2) and assuming $\mathrm{a}_{10}$ of 2 and a conversion factor from dry weight to carbon of $50 \%$.

\section{RESULTS}

Temperature ranged from 0 to $22{ }^{\circ} \mathrm{C}$ during the 3 periods, while salinity was 11 to $13 \%$ (Table 3 ). Recapture of the added fish at the end of each period showed that $70 \%$ of the fish survived the April experiment, $35 \%$ the June/July experiment and $90 \%$ the September experiment.

The number of tintinnid ciliates decreased in all enclosures during the 3 experiments, but the decrease was most pronounced in the enclosures with added mussels (Fig. 1). The mean length of ciliates Tintinnopsis spp. were 65, 95 and $80 \mu \mathrm{m}$ during April, June/July and September, respectively During June/July numbers decreased from more than $1000 \mathrm{l}^{-1}$ to $20 \mathrm{l}^{-1}$ in the

Table 2. Literature used in the conversion of abundance data to biomass and clearance

\begin{tabular}{|lll|}
\hline Taxon & Biomass & Clearance \\
\hline Tintinnopsis spp. & Fenchel \& Finlay (1983) & Fenchel (1986) \\
Synchaeta spp. & Hernroth (1985), Schinder \& Noven (1971) & Starkweather (1980) \\
Polychaete larvae & K. Johansen (pers. comm.) & As bivalve larvae \\
Gastropod larvae & Pechenik (1980) & Pechenik (1980) \\
Bivalve larvae & Jespersen \& Olsen (1982) & Jespersen \& Olsen (1982) \\
Pleopis polyphemoides & Hernroth (1985) & \\
Acartia tonsa & Berggreen et al. (in press) & Berggreen et al. (in press) \\
Balanus spp. nauplii & Rodhouse \& Roden (1987) & F. Mohlenberg (unpubl.) \\
\hline
\end{tabular}


Table 3. Temperature range and salinity during the 3 experimental periods

\begin{tabular}{|lcc|}
\hline & $\begin{array}{c}\text { Temperature range } \\
\left({ }^{\circ} \mathrm{C}\right)\end{array}$ & $\begin{array}{c}\text { Salinity } \\
(\%)\end{array}$ \\
\hline April & $0-9$ & 11 \\
June/July & $17-22$ & 13 \\
September & $11-12$ & 11 \\
\hline
\end{tabular}

enclosures with added mussels, while the decrease in the enclosures without mussels was less pronounced (Fig. 1A). Lower numbers were recorded during the April and September experiments, and during April similar changes in the number of tintinnids were found in all enclosures.

The initial number of rotifers in April was about $400 \mathrm{l}^{-1}$, decreasing to $75 \mathrm{l}^{-1}$ in enclosures with added mussels and $250 \mathrm{l}^{-1}$ in enclosures without mussels (Fig. 1B). During June/July the number of rotifers decreased from about $150 \mathrm{l}^{-1}$ to 10 and $35 \mathrm{I}^{-1}$ in enclosures with and without mussels, respectively (Fig. 1B). In September only few Synchaeta were recorded at the start of the experiment. In enclosures without mussels their number peaked at more than $100 \mathrm{l}^{-1}$ in the middle of the experiment, while the number was stable at about $5 \mathrm{I}^{-1}$ in the mussel enclosures (Fig. 1B).
In contrast to the predation on Tintinnopsis spp. and Synchaeta spp., mussels had no effect on the abundance of the copepod Acartia tonsa (Fig. 2), although $M$. edulis can efficiently clear ambient water of Artemia salina nauplii (Jorgensen 1975).

The addition of fish Gasterosteus aculeatus influenced the abundance of Acartia tonsa. In April the initial number of $A$. tonsa was low, but the abundance of copepodites and adults increased during the experiment (Fig. 2). The increase in copepodites and adults was most pronounced in enclosures without fish. Numbers of nauplii were nearly constant during April in all enclosures. Larger effects of planktivorous fish were found in June/July. Numbers of copepodites and adults showed an 8-fold increase and nauplii more than a 40fold increase in enclosures without fish, compared to reduced numbers of copepodites and adults and a nearly constant number of nauplii in enclosures with fish (Fig. 2). Only minor changes in numbers of the different developmental stages were seen in enclosures without fish during September, while decreasing numbers were measured in enclosures with fish (Fig. 2).

At the beginning of the June/July experiment 20 to 60 individuals $\mathrm{m}^{-3}$ of the raptorial cladoceran Pleopis polyphemopides were recorded (Fig. 3). Lower number of this species were found in enclosures with fish while a 5- to 250 -fold increase was seen in enclosures without fish.

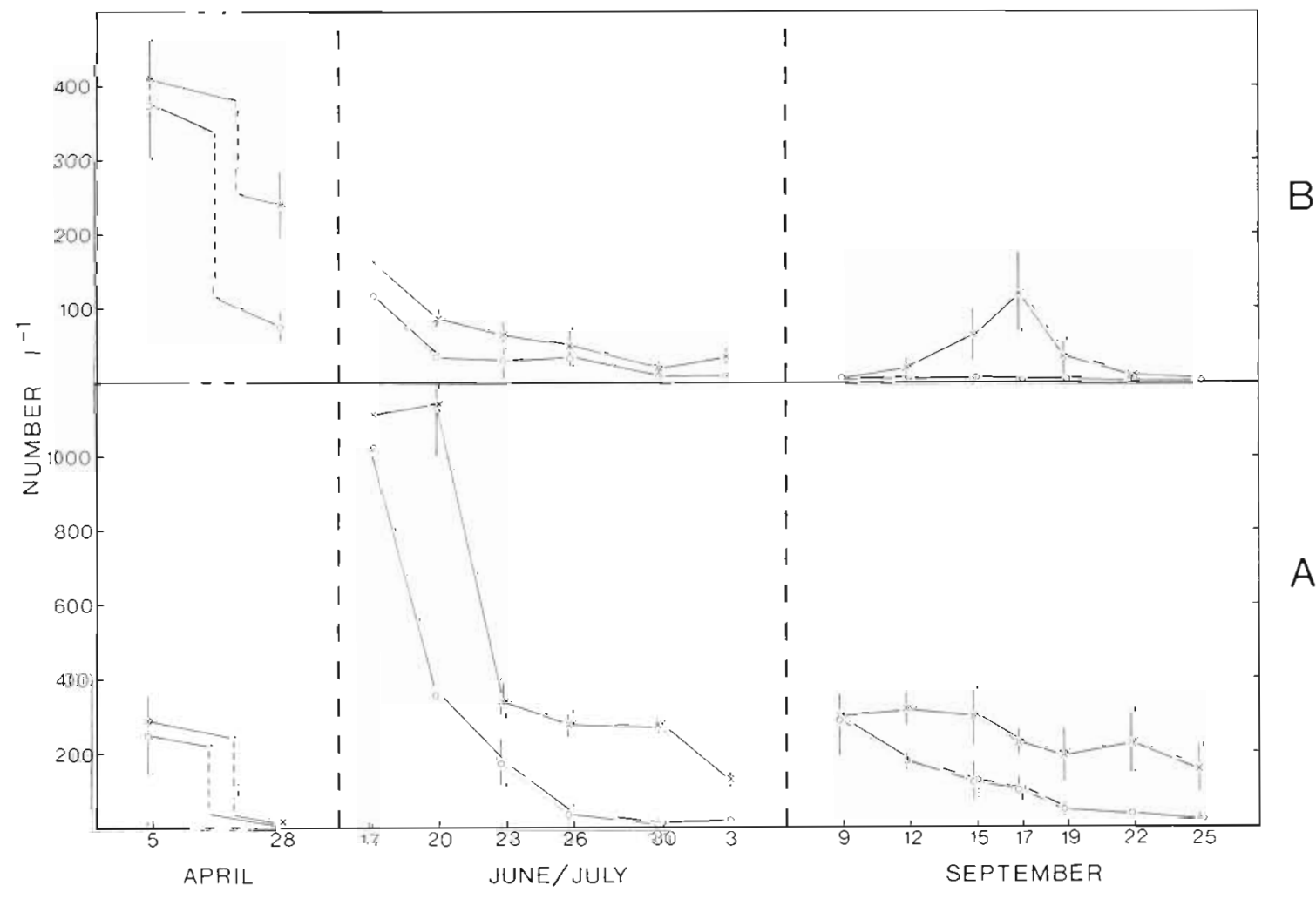

Fig. 1. Numbers of (A) tintinnid ciliates Tintinnopsis spp. and (B) rotifers Synchaeta spp. during the 3 experimental periods in enclosures with added mussels (0), and without mussels $(x)$. Bars represent standard deviation $(n=12)$ 
Addition of suspension-feeding bivalves and planktivorous fish had considerable effects on biomass ( $\mathrm{mg} \mathrm{C}$ $\left.\mathrm{m}^{-3}\right)$ and calculated clearance $\left(1 \mathrm{~m}^{-3} \mathrm{~d}^{-1}\right)$ of the zooplankton $>45 \mu \mathrm{m}$ (Fig. 4). During April, total biomass decreased in all enclosures, while total clearance increased in enclosures without fish and decreased in enclosures with added fish (Fig. 4). The increase in estimated total clearance in some enclosures, in spite of decreased biomass, was caused by enhanced clearance by the zooplankton as a result of higher temperatures. Biomass and clearance of Tintinnopsis spp. decreased in all enclosures to respectively 4 and $7 \%$ of initial levels. Synchaeta spp. accounted for the major part of the biomass and clearance at the beginning of the experiment. In enclosures without mussels, Synchaeta spp. maintained a high biomass and clearance, while their importance decreased in enclosures with mussels. Biomass of Acartia tonsa increased during April in enclosures without fish, and their clearance increased likewise.

In June/July the total zooplankton biomass and especially the total clearance were higher than in April, and additional species appeared in the samples (Fig. 4). Meroplanktonic species included larvae of polychaetes (Nereis spp. and Polydora sp.), gastropods (Hydrobia spp.), bivalves (mainly Mytilus edulis) and especially cirripedes (Balanus spp.); they accounted for $25 \%$ of the biomass and $5 \%$ of the clearance at the start of this experiment, but their importance decreased during the period. The cladoceran Pleopis polyphemoides appeared in all enclosures at the start, but with low biomass. During the experiment their biomass increased in enclosures without fish and decreased in enclosures with added fish. Tintinnopsis spp. accounted for more than one-third of the biomass, and about $90 \%$ of the clearance at the start, decreasing in both relative and absolute importance during the period, especially in enclosures containing mussels Synchaeta spp. showed the same tendencies as Tintinnopsis spp., although less pronounced, and clearance of these species constituted a smaller part of the zooplankton clearance. Biomass of Acartia tansa was low at the beginning of the period, and clearance of the species accounted for a minor part of the total clear-

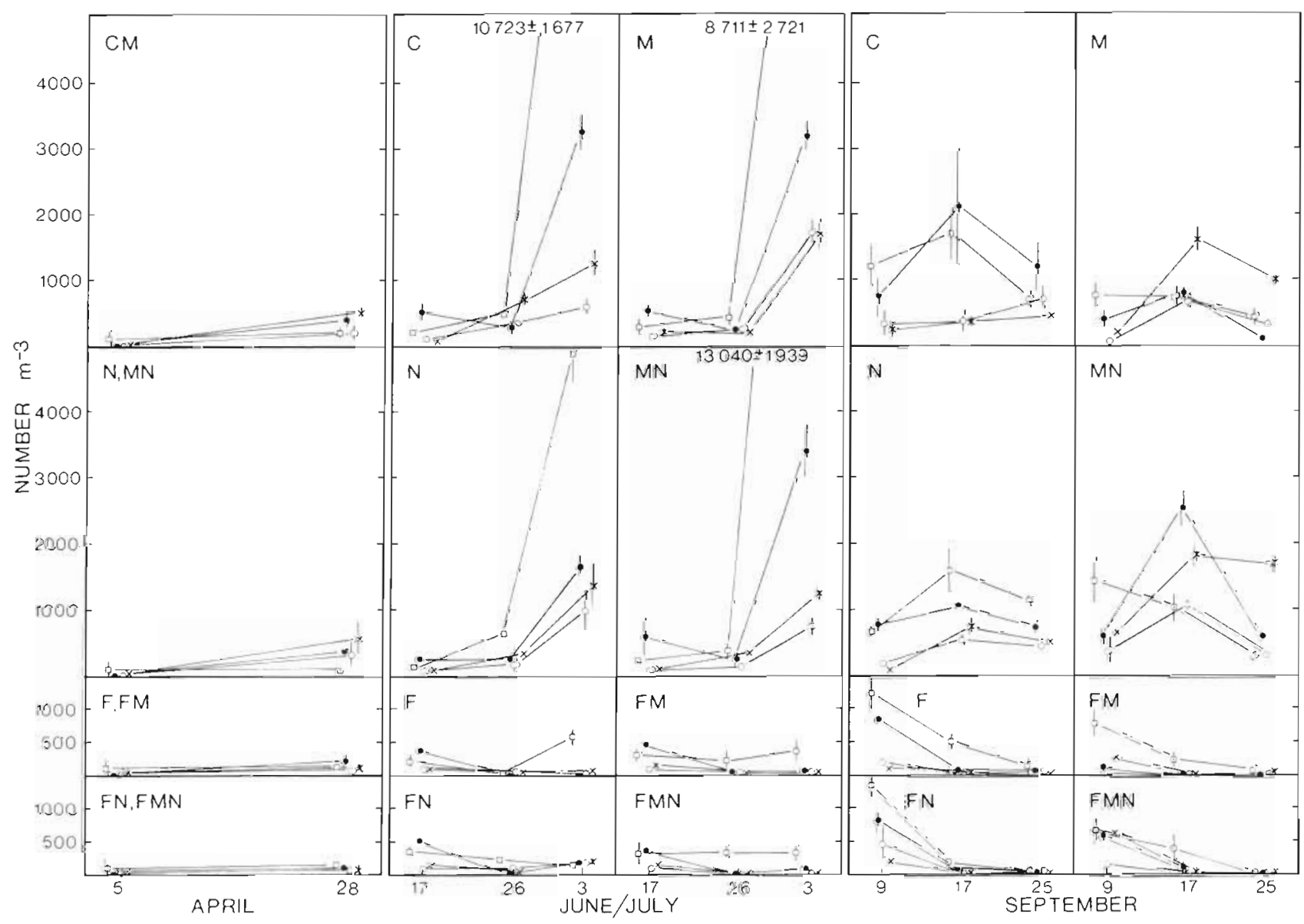

Fig. 2. Changes in numbers of the copepod Acartia tonsa during the 3 experiments. $(E)$ Nauplii $\times 10^{-1} ;(\bullet)$ copepodites I $+I_{i}(0)$ copepodites III + IV; $(x)$ copepodites $V+$ adults. Bars represent standard deviation $(n=6)$ 


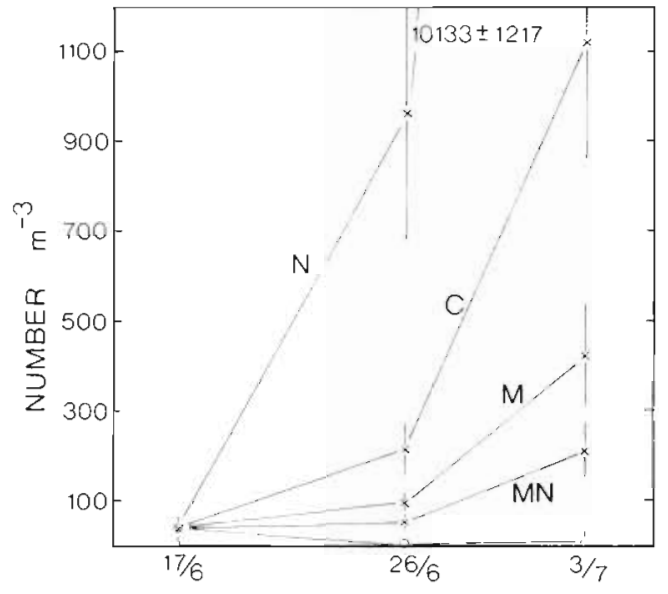

Fig. 3. Changes in numbers of the cladoceran Pleopsis polyphemoides during the June/July experiment in enclosures (0) with $(n=12)$ and $(x)$ without fish $(n=3)$. Bars represent standard deviation

ance. Its biomass remained low in enclosures with added fish, while the species became dominant with respect to both biomass and clearance in enclosures without fish.

The development of biomass and the clearance of the zooplankton community during September followed the same trends as in June/July, but the initial biomass of the species was lower except for A. tonsa (Fig. 4), and together with a decreased clearance caused by lower temperatures, total clearance was also lower than in June/July.

\section{DISCUSSION}

\section{Nutrient enrichment}

During the present study effects of nutrient enrichment were not measurable on zooplankton biomass, although a pronounced increase in chlorophyll concentration was observed during the June/July and September experiments (Riemann et al. 1988). Other marine enclosure experiments have shown that nutrient enrichment increases chlorophyll levels and copepod (Acartia tonsa) production (Fulton 1984). Parsons et al. (1977) found that the addition of nutrients had little effect on the zooplankton community, and concluded that zooplankton composition was controlled by predation from ctenophores. The absence of an effect of nutrient addition suggests that zooplankton production was not food limited in our experiment, hence, the fertilized enclosures are treated together with the controls. The discussion accordingly focuses on the effect of suspension-feeding bivalves and planktivorous fish on zooplankton.

\section{Predation by bivalves on microzooplankton}

Suspension-feeding bivalves possess a large filtration capacity. In Roskilde Fjord the average biomass theoretically filters the water column twice a day (Riemann et al. 1988). Unfortunately the major part of the literature concerning filtration of Mytilus edulis focuses on the lower limit of the particle-retention spectrum. To our knowledge, there are no available data on the importance of small zooplankton species in the diet of suspension-feeding bivalves. Since particles from 2 to $200 \mu \mathrm{m}$ are retained by $M$. edulis (Jørgensen \& Goldberg 1953, Møhlenberg \& Riisgård 1979), suspension-feeding bivalves may act as a major controlling element on small zooplankton species. Because protozooplankton and smaller zooplankton species constitute an important link in the flow of organic matter in marine environments (Azam et al. 1983), predation by suspension-feeding bivalves could be of major importance.

No effect of Mytilus edulis on the size of the Tintinnopsis population was found during the April experiment. The biomass decreased at the same rate in enclosures with and without mussels. In the major part of this experiment the low temperatures probably limited the clearance of the mussels (Schulte 1975). Filtration of mussels reduced the number of Tintinnopsis spp. during the June/July and September experiments (Fig. 1A). In both experiments the biomass of Tintinnopsis spp. stabilized at ca 300 individuals $1^{-1}$ in enclosures without mussels, while their biomass in the mussel enclosures was considerable lower (Fig. 1A).

During April and June/July addition of mussels resulted in a faster reduction in the number of Synchaeta spp. than during September (Fig. 1B). In the September experiment the biomass of Synchaeta spp. was very low in the mussel enclosures. In contrast, the biomass increased and peaked during the middle of the experiment in the enclosures without mussels. In the enclosures with added mussels the mean length of rotifers was larger than in enclosures without mussels (180 and $115 \mu \mathrm{m}$ respectively), suggesting that smail rotifers were preferred by the mussels.

\section{Predation on zooplankton}

Addition of mussels did not influence the development of Acartia tonsa (Fig. 2) and the meroplankton (Fig. 4), although Mytilus edulis is reported to ingest particles up to about $200 \mu \mathrm{m}$ (Jørgensen \& Goldberg 1953). Presumably these zooplankters can perceive and escape the inhalant current of the mussels.

Effects of planktivorous fish on the zooplankton were mainly seen as a decrease in the abundance of the 

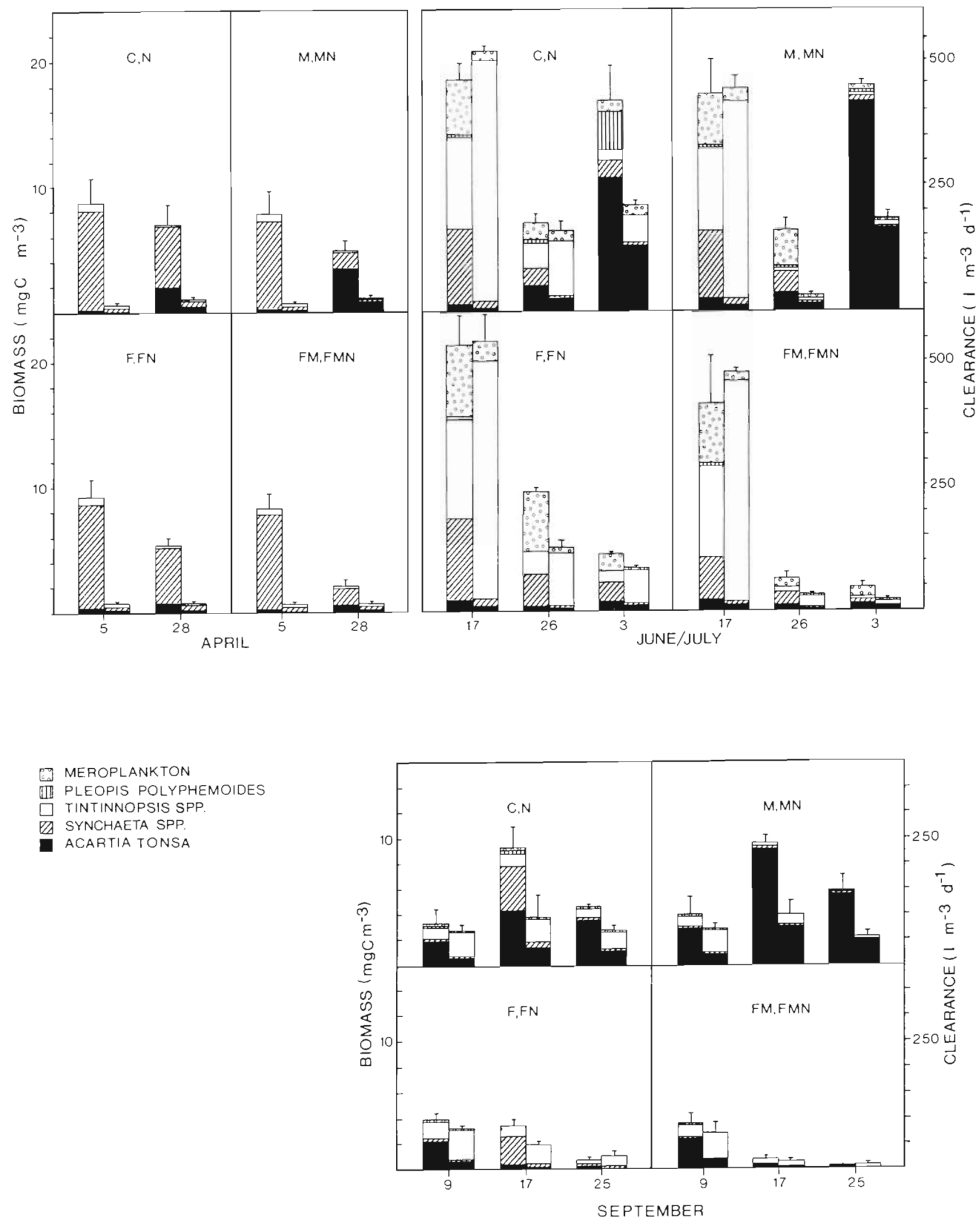

Fig. 4. Zooplankton biomass (left columns) and clearance (right columns) during April. June/July and September. Bars represent standard deviation $(n=6)$ 
larger holozooplanktonic species (Acartia tonsa and Pleopis polyphemoides: Figs. 2 to 4). No measurable effect was seen on the merozooplankton, probably because it was dominated by bivalve larvae with a diameter less than $150 \mu \mathrm{m}$ and by nauplii of Balanus spp. Both disappeared from the pelagic system in the enclosures without fish because of settling. The decreased number of $A$. tonsa nauplii in the enclosures with added fish was probably caused by low recruitment, since the adults were eaten within a few days. Decreased biomasses of $A$. tonsa and $P$. polyphemoides could be expected to result in increased numbers of Tintinnopsis spp., since protozooplankton are an important food source for A. tonsa (Robertson 1983, Stoeckner \& Sanders 1985) as well as for $P$. polyphemoides (Poggensee \& Lenz 1981). This effect was, however, not observed during our experiments. Also no effect of Gasterosteus aculeatus on Synchaeta spp. was seen. The highly variable numbers of $P$. polyphemoides in enclosures without fish at the end of the June/July experiment are probably due to differences in initial numbers of individuals (Fig. 3), since parthenogenetic marine cladocerans have a high reproductive rate (Makrushin 1981, Poggensee \& Lens 1981), but food competition from $M$. edulis might also influence the development of $P$. polyphemoides, since the number of ciliates in enclosures with added mussels was lower than in the controls.

Our results demonstrate that Gasterosteus aculeatus prefers larger zooplankton species, which agrees with Gibson (1984), who found that $G$. aculeatus feeding on a mixed population of Daphnia preferentially exploited the larger prey. Moreover, Fulton (1984) found that predation by size-selective planktivorous fish prevented dominance by larger zooplankton species in estuaries. Fulton (1984) found in enclosures without fish that Acartia tonsa dominated compared to the smaller copepods (Parvocalanus crassirostris and Oithona colvarva), while addition of fish favoured the small zooplankton species. Investigations in freshwater have shown the same trends (e.g. Brooks \& Dodson 1965). As a secondary effect of planktivorous fish, phytoplankton biomass may increase, as a result of the decreased grazing by herbivorous zooplankters (Anderson et al. 1978, Stenson et al. 1978, Henrikson et al. 1980, Goad 1984). This secondary effect was confirmed by our experiments, where a $20 \%$ increase in phytoplankton biomass was measured during June/ July and September, compared to respective control enclosures (Riemann et al. 1988).

Pronounced effects of Gasterosteus aculeatus were found during June/July and September (Figs. 2 to 4), when temperatures were above $11^{\circ} \mathrm{C}$ (Table 2), despite the fact that survival of the fish was only $35 \%$ during June/July compared to 70 and $90 \%$ during April and
September, respectively. The fish probably starved to death, since their calculated maintainance rations following Allan \& Wootton (1982), exceeded available zooplankton during all 3 periods.

\section{Zooplankton clearance rates}

The calculated maximum clearance of the zooplankton community $>45 \mu \mathrm{m}$ was about 3,50 and $10 \%$ of the water column per day during April, June/July and September, respectively. This is of minor importance for the regulation of the phytoplankton biomass, compared to the clearance of Mytilus edulis, which was about 55,220 and $120 \%$ of the water column per day respectively. This difference is probably not as pronounced in the fjord, where the bivalves are situated at the bottom, rather than suspended in nets in the water column.

In conclusion our results demonstrate that in Roskilde Fjord the holoplanktonic crustaceans are strongly predator controlled, especially during summer, since the increased phytoplankton biomass in the fertilized enclosures did not increase the abundance of Acartia tonsa and Pleopis polyphemoides while 'exclusion' of the fish resulted in an immense increase. The zooplankton community $>45 \mu \mathrm{m}$ was controlled in 2 ways in the enclosures; larger zooplankton were preyed upon by Gasterosteus aculeatus, and microzooplankton by Mytilus edulis. Two important problems need further investigation: (1) the importance of small zooplankton species in the diet of suspension-feeding bivalves, and (2) the effect of this predation on cycling of organic matter in estuarine environments.

Acknowledgements. This work was supported by the Danish Environmental Protection Agency. We thank Jens Borum, C. Barker Jørgensen, Thomas Kiorboe and C. A. Oviatt for critically commenting on the manuscript and Flemming Heegaard, Anders Klenov, Winnie Martinsen, Finn Pedersen and Jan Steensgaard for technical assistance.

\section{LITERATURE CITED}

Allan, J. R. M., Wootton, R. J. (1982). The effect of ration and temperature on the growth of the three-spined stickleback, Gasterosteus aculeatus L. J. Fish Biol. 20: 409-422

Andersen, P., Sorensen, H. M. (1986). Population dynamics and trophic coupling in pelagic microorganisms in eutrophic coastal waters. Mar. Ecol. Prog. Ser, 33: 99-109

Andersson, G., Berggren, H., Croneberg, G., Gelin, C. (1978). Effects of planktivorous and benthivorous fish on organisms and water chemistry in eutrophic lakes. Hydrobiologia 59: 9-15

Azam, F., Fenchel, T., Field, J. G., Gray, J. S., Meyer-Reil, L. A., Thingstad, F. (1983). The ecological role of watercollumn microbes in the sea. Mar. Ecol. Prog. Ser. 10 $257-263$ 
Berggreen, U., Hansen, B., Kiorboe, T (in press). Food size spectra, ingestion and growth rate of the copepod Acartia tonsa during development: implication for the determination of copepod production. Mar Biol.

Brooks, J. L., Dodson, S. I. (1965). Predation, body size and composition of plankton. Science 150: 28-35

Cloern, J. E. (1982). Does the benthos control phytoplankton biomass in south San Francisco bay? Mar Ecol. Prog. Ser. 9: $191-202$

Dame, R., Zinkmark, R., Stevenson, H., Nelson, D. (1980). Filter feeder coupling between the estuarine water column and benthic subsystems. In: Kennedy, V S. (ed.) Estuarine perspectives. Academic Press, New York, p. 521-526

Fenchel, T., Finlay, B. J. (1983). Respiration rates in heterotrophic, free-living protozoa. Microb. Ecol. 9: 99-122

Fenchel, T (1986). Protozoan filter feeding. Prog. Protistol. 1. $65-113$

Fulton, R. F. (1984). Predation, production and organization of an estuarine copepod community. J. Plankton Res. 6 (3): 399-415

Gibson, R. M. (1984). Optimal prey-size selection by threespined sticklebacks (Gasterosteus aculeatus): a test of the apparent-size hypothesis. Z. Tierpsychol. 52: 291-307

Gislason, H. (1980). Fødekæden i Roskilde fjord. Fisk \& Hav 1979-1980: 23-28. (Danish)

Goad, J. (1984). A biomanipulation experiment in Green Lake, Seattle, Washington. Arch. Hydrobiol. 102 (2): 137-153

Henrikson, L., Nyman, H. G., Oscarson, H. G., Stenson, J. A. E. (1980). Trophic changes, without changes in the external nutrient loading. Hydrobiologia 68: 257-263

Hernroth, L. (1985). Recomendations on methods for marine biological studies in the Baltic Sea. Mesozooplankton biomass assassment. The Baltic Marine Biologists - Publication No. 10

Jespersen, H., Olsen, K. (1982). Bioenergetics in veliger larvae of Mytilus edulis L. Ophelia 21 (1): 101-113

Johansson, L., Persson, L. (1986). Planktivorous fish. In: Riemann, B., Sondergaard, M. (eds.) Carbon dynamics in eutrophic, temperate lakes. Elsevier, New York, p. $237-260$

Jonsson, P. R. (1986). Particle-size selection, feeding rates and growth dynamics of marine planktonic oligotrichous ciliates (Ciliophora: oligotrichina). Mar. Ecol. Prog. Ser. 33: $265-277$

Jørgensen, C. B. (1975). On the gill function in the mussel Mytilus edulis L. Ophelia 13: 187-232

Jorgensen, C. B., Goldberg, E. D. (1953). Particle filtration in some ascidians and lamellibranchs. Biol. Bull. mar. biol. Lab., Woods Hole 105: 477-489

Kautsky, N. (1981). On the role of the blue mussel, Mytilus edulis L in the Baltic ecosystem. Thesis Department of Zoology and Askø Laboratory, University of Stockholm, Sweden

Makrushin, A. V (1981). Hypothesis of the cause of incomplete correlation between generation cycles and dynamics of environmental conditions in Podonidae. Biol. Morja, Vladiv. 7: 26-29

Miller, P. J (1979). Adaptiveness and implications of small size in Teleosts. Symp. zool. Soc. London 44: 263-306

Mohlenberg, F, Riisgard, H. U. (1979). Filtration rate, using a new indirect technique, in thirteen species of suspension feeding bivalves. Mar. Biol. 54: 143-147

Nixon, S. W., Pilson, M. E. Q. (1983). Nitrogen in estuarine and costal ecosystems. In: Carpenter, E. J., Capone, D. G. (eds.) Nitrogen in the environment. Academic Press, New York, p. $565-648$

Parsons, T. R., von Bröckel, K., Koeller, P., Takahashi, M., Reeve, M. R., Holm-Hansen, O. (1977). The distribution of organic carbon in a marine planktonic food web following nutrient enrichment. J. exp. mar. Biol. Ecol. 26 : $235-247$

Pechenik, H. A. (1980). Growth and energy balance during the larval lives of three prosobranch gastropods. J. exp. mar Biol. Ecol. 44: 1-28

Poggensee, E., Lenz, J. (1981). On the population of two brackish-water Cladocera Podon leuckarti und Evadne nordmanni in Kiel fjord. Kieler Meeresforsch. Sonderh. 5: $258-273$

Robertson, J. R. (1983). Predation by estuarine zooplankton on tintinnid ciliates. Estuar. coast. Shelf Sci. 16 (1): 27-36

Riemann, B., Nielsen, T. G., Horsted, S. J., Bjornsen, P. K., Pock-Steen J. (1988). Regulation of phytoplankton biomass in estuarine enclosures. Mar. Ecol. Prog. Ser. 48: 205-215

Rodhouse, P. G., Roden, C. M. (1987). Carbon budget for a coastal inlet in relation to intensive cultivation suspensionfeeding bivalve molluscs. Mar. Ecol. Prog. Ser. 36: 225-236

Schinder, D. W., Noven, B. (1971). Vertical distribution and seasonal abundance of zooplankton in two shallow lakes of the experimental lake area, North western Ontario. J. Fish. Res. Bd Can. 28: 245-256

Schulte, E. H. (1975). Influence of algal concentration and temperature on the filtration rate of Mytilus edulis. Mar. Biol. 30: 331-341

Starkweather, P. L. (1980). Aspects of the feeding behavior and trophic ecology of suspension-feeding rotifers. Hydrobiologia 73: 63-72

Stenson, J. A. E., Bohlin, T., Henrikson, L. Nilson, Nyman, H G., Oscarson, H. G., Larsson (1978). Effects of fish removal from a small lake. Verh. int. Verein. Limnol. 20: 794-801

Stoecker, D. K., Sanders, N. K. (1985). Differental grazing by Acartia tonsa on a dinoflagellate and a tintinnid. J. Plankton Res. 7: 85-100

Zander, C. D., Hartwig, E. (1982). On the biology of smallsized fish from North and Baltic sea areas. IV Investigations on an eulittoral mud flat at Sylt island. Helgoländer Meeresunters. 35: 47-63

Zander, C. D., Buchner, J. M., Totzke, H.-D. (1984). The role of the sticklebacks in the food web of the Elbe and the estuaries (Northern Federal Republic of Germany). Zool. Anz. $212(3-4): 209-222$ 